\section{Analysis of Ploidy Level and Its Effects on Guard Cell Length, Pollen Diameter, and Fertility in Hydrangea macrophylla}

Keri D. Jones and Sandra M. Reed ${ }^{1}$

Floral and Nursery Plants Research Unit, U.S. National Arboretum, Agricultural Research Service, U.S. Department of Agriculture, Tennessee State University Otis L. Floyd Nursery Research Center, 472 Cadillac Lane, McMinnville, TN 37110

\section{Timothy A. Rinehart \\ Southern Horticultural Laboratory, Agricultural Research Service, U.S. Department of Agriculture, 810 Highway 26 West, Poplarville, MS 39470}

Additional index words. flow cytometry, chromosome number, triploidy, unreduced gametes, bigleaf hydrangea, mountain hydrangea

\begin{abstract}
Ploidy level was estimated in Hydrangea macrophylla (Thunb) Ser. using flow cytometry. For H. macrophylla ssp. macrophylla, 42 diploid and 19 triploid cultivars were identified. All $14 \mathrm{H}$. macrophylla ssp. serrata (Thunb.) Makino cultivars tested were diploids. Somatic chromosome counts confirmed the ploidy of three diploid $(2 n=2 x=36)$ and three triploid $(2 n=3 x=54)$ cultivars. Stomatal guard cell length and pollen diameter of $H$. macrophylla ssp. macrophylla diploid cultivars were smaller than those of triploid cultivars. However, because the range of measurements for the diploids overlapped that of the triploids, neither guard cell nor pollen measurements are recommended for determining ploidy of $\boldsymbol{H}$. macrophylla cultivars. Fertility was estimated using pollen staining and controlled pollinations. Stainable pollen for triploid cultivars averaged $63 \%$ and ranged from 25\% in 'Masja' to 85\% in 'Marechal Foch'. Viable seed was obtained when four triploid cultivars were used as pistillate or staminate parents in controlled pollinations to diploid $\boldsymbol{H}$. macrophylla ssp. macrophylla cultivars. A bimodal distribution of pollen sizes, which is suggestive of unreduced gamete production, was observed in one cultivar; however, more detailed genetic and cytologic studies are needed to elucidate the mechanism behind triploid formation in $H$. macrophylla taxa.
\end{abstract}

Hydrangea macrophylla is widely grown as both a landscape and florist plant. In the landscape, it is valued for its large, longlasting inflorescences that are produced in early summer. As a florist's plant, it is usually forced into bloom for Easter and Mother's Day sales (Bailey, 1989). Although only $H$. macrophylla ssp. macrophylla is used in the florist's trade, both $H$. macrophylla ssp. macrophylla (bigleaf hydrangea) and $H$. macrophylla ssp. serrata (mountain hydrangea) are sold as garden plants. The two subspecies are differentiated by the larger leaves and inflorescences of H. macrophylla ssp. macrophylla (McClintock, 1957). Interest in the species has increased in recent years as a result of the introduction of cultivars with new inflorescence forms and color patterns from Europe and Japan and the identification

\footnotetext{
Received for publication 6 Dec. 2006. Accepted for publication 1 Feb. 2007.

Mention of trade names of commercial products in the publication is solely for the purpose of providing specific information and does not imply recommendation or endorsement by the U.S. Dept. of Agriculture.

${ }^{1}$ To whom reprint requests should be addressed; e-mail sreed@blomand.net
}

A somatic chromosome number of $2 n=$ $2 x=36$ was first reported for $H$. macrophylla in 1957 (Haworth-Booth, 1984). Funamoto and Tanaka (1988) confirmed this number using $H$. macrophylla ssp. serrata plants collected from five locations. Kudo and Niimi (1999) reported 52 chromosomes in H. macrophylla ssp. macrophylla 'Blaumeise' [syn. 'Blue Sky' (Bertrand, 2001)].

DNA content of $H$. macrophylla has been investigated using flow cytometry. Working with 4',6-diamidino-2-phenylidole (DAPI)stained nuclei, Demilly et al. (2000) found 100 diploid and 21 triploid H. macrophylla ssp. macrophylla cultivars. All 23 H. macrophylla ssp. serrata taxa examined were diploids. Unfortunately, these authors did not list names of any cultivar evaluated in this study. They reported that flow cytometric results were supported by chromosome counts with diploids having 36 and triploids having 54 chromosomes, but no details as to cultivars examined or number of cells counted were provided. Flow cytometric measurements of nuclear DNA content of five $H$. macrophylla ssp. macrophylla and five $H$. macrophylla ssp. serrata plants were made using DNA intercalating, GC-specific and AT-specific fluorochromes (Cerbah et al., 2001). The H. macrophylla ssp. macrophylla plants had $11.7 \%$ more nuclear DNA than the H. macrophylla ssp. serrata plants. Both subspecies had similar GC percentages of 41.0 and $40.6 \%$, respectively. Chromosome counts were also made from root tips. All plants examined had 36 chromosomes. Plants included in this study were identified by accession number rather than cultivar name.

The most recent study of ploidy differences within $H$. macrophylla was reported by Zonneveld (2004). Propidium iodide-stained nuclei of $25 \mathrm{H}$. macrophylla ssp. macrophylla and $18 \mathrm{H}$. macrophylla ssp. serrata taxa were examined using flow cytometry. All of the H. macrophylla ssp. serrata and 16 of the H. macrophylla ssp. macrophylla plants were found to be diploids. The remaining H. macrophylla ssp. macrophylla plants were identified as triploids. Although cytological data were not presented, the author stated that triploidy was verified from chromosome counts of root tip cells. The H. macrophylla ssp. serrata taxa had $\approx 5.8 \%$ less nuclear DNA than the diploid H. macrophylla ssp. macrophylla cultivars.

Information on ploidy level of specific H. macrophylla cultivars will help in selecting parents for both intra- and interspecific hybridizations. The objective of this study was to evaluate ploidy in a diverse group of H. macrophylla cultivars. Ploidy was first estimated using flow cytometry and then confirmed in selected diploid and triploid plants using chromosome counts. The potential for using stomatal guard cell length and pollen grain size to identify ploidy level of $H$. macrophylla plants was also examined. Finally, fertility of triploid cultivars was estimated through pollen staining and controlled pollinations. 


\section{Materials and Methods}

Plant materials. Cuttings were taken in Summer 2005 from a single plant each of 75 $H$. macrophylla cultivars, including $61 \mathrm{mem}-$ bers of $H$. macrophylla ssp. macrophylla and 14 members of $H$. macrophylla ssp. serrata, growing at the Tennessee Nursery Research Center, McMinnville, Tenn. Cuttings were dipped for $5 \mathrm{~s}$ in $4.9 \mathrm{~mm}$ indole-3-butyric acid in $50 \%$ ethanol, stuck into 4 pine bark : 1 peatmoss (by volume), and placed under mist in a greenhouse. One rooted cutting of each cultivar was used for the flow cytometric analysis. Another rooted cutting of each cultivar was overwintered in an unheated greenhouse and used for pollen measurements in Spring 2006. A third rooted cutting of six cultivars was used for chromosome counts. Stomatal measurements were made on leaf tissue collected from the original plant.

Flow cytometry. Flow cytometric measurements of nuclear DNA quantity were made from all 75 cultivars listed in Table 1. Approximately $0.5 \mathrm{~cm}^{2}$ of growing leaf tissue of sample and standard were chopped for 30 to $60 \mathrm{~s}$ in a plastic petri dish containing $0.4 \mathrm{~mL}$ extraction buffer (Partec CyStain ultraviolet precise P Nuclei Extraction Buffer; Partec GMBH, Münster, Germany). The resulting extract was passed through a $30-\mu \mathrm{L}$ filter into a $3.5-\mathrm{mL}$ plastic tube to which was added 1.6 mL Partec CyStain ultraviolet precise $\mathrm{P}$ Staining Buffer containing the fluorochrome DAPI. The relative fluorescence of the total DNA was measured for each nucleus using a Partec PA-1 ploidy analyzer (Partec GMBH). For each sample, at least 3000 nuclei were analyzed revealing a single peak with a coefficient of variation (cv) less than $4.9 \%$. Genome sizes were calculated as nuclear DNA content for unreduced tissue (2C) as: 2C DNA content of tissue $=($ mean fluorescence value of sample $\div$ mean fluorescence value of standard) $\times 2 \mathrm{C}$ DNA content of standard. Pisum sativum L. 'Ctirad' with a 2C content of 9.09 pg (Doležel and Bartoš, 2005) was used as the internal standard.

Chromosome counts. Based on flow cytometric results, three diploid and three triploid ssp. macrophylla cultivars were chosen for chromosome counts. Root tips were collected from actively growing plants immersed in $0.1 \mathrm{~mm}$ colchicine for $3 \mathrm{~h}$ at room temperature $\left(20^{\circ} \mathrm{C}\right)$, rinsed in distilled water, and fixed in a solution of $95 \%$ ethanol:chloroform:acetic acid $(6: 3: 1, \mathrm{v} / \mathrm{v} / \mathrm{v})$ for $24 \mathrm{~h}$ at room temperature. Root tips were transferred to $70 \%$ ethanol and stored at $-20{ }^{\circ} \mathrm{C}$ until needed. Before examination, root tips were hydrolyzed in $5 \mathrm{~N} \mathrm{HCl}$ for $7 \mathrm{~min}$, rinsed with distilled water, and soaked in $1 \%$ acetocarmine for $20 \mathrm{~min}$. The meristematic region of the root tip was squashed in aceto-carmine and chromosomes counted. Chromosome counts were made from five metaphase cells for each of the six cultivars examined.

Stomatal guard cell length. Based on flow cytometric results, five diploid and five triploid H. macrophylla ssp. macrophylla
Table 1. Ploidy, total nuclear DNA, percent stainable pollen, and pollen size of cultivars of two subspecies of Hydrangea macrophylla.

\begin{tabular}{|c|c|c|c|}
\hline $\operatorname{Taxa}^{\mathrm{z}}$ & $\begin{array}{l}\text { Total nuclear } \\
\text { DNA, } \text { pg }^{\mathrm{y}}\end{array}$ & $\begin{array}{l}\text { Stainable pollen, } \\
\%(\text { mean } \pm \mathrm{sE})\end{array}$ & $\begin{array}{c}\text { Pollen grain } \\
\text { diam., } \mu \mathrm{m} \\
(\text { mean } \pm \mathrm{sE})\end{array}$ \\
\hline \multicolumn{4}{|c|}{ Diploid H. macrophylla ssp. macrophylla cultivars } \\
\hline All Summer Beauty & 4.79 & $79 \pm 3.2$ & $8.3 \pm 0.06$ \\
\hline Alpengluhen* & 4.75 & $79 \pm 2.9$ & $8.4 \pm 0.06$ \\
\hline Ayesha* & 4.97 & $98 \pm 0.8$ & $9.0 \pm 0.05$ \\
\hline Bailmer (Endless Summer) & 4.74 & $89 \pm 1.6$ & $8.1 \pm 0.05$ \\
\hline Beauté Vendômoise & 4.73 & $57 \pm 1.3$ & $8.5 \pm 0.06$ \\
\hline Blauer Prinz & 4.83 & $71 \pm 2.0$ & $8.4 \pm 0.06$ \\
\hline Blauling & 4.85 & - & - \\
\hline Blue Wave (Mariesii Perfecta)* & 4.78 & $54 \pm 1.9$ & $8.4 \pm 0.06$ \\
\hline David Ramsey & 4.82 & $89 \pm 0.3$ & $8.7 \pm 0.06$ \\
\hline Decatur Blue & 4.78 & $78 \pm 5.2$ & $8.1 \pm 0.06$ \\
\hline Dooley & 4.79 & $83 \pm 0.9$ & $8.2 \pm 0.06$ \\
\hline Early Sensation (Forever and Ever) & 4.72 & $84 \pm 0.8$ & $8.6 \pm 0.06$ \\
\hline Elster & 4.79 & $20 \pm 4.8$ & $10.4 \pm 0.11$ \\
\hline Fasan & 4.86 & $71 \pm 1.0$ & $8.9 \pm 0.06$ \\
\hline Général Vicomtesse de Vibraye & 4.75 & $80 \pm 1.6$ & $8.1 \pm 0.05$ \\
\hline Harlequin & 4.82 & $90 \pm 0.5$ & $9.1 \pm 0.06$ \\
\hline Horben & 4.81 & $82 \pm 3.2$ & $8.2 \pm 0.07$ \\
\hline Kluis Superba & 4.67 & $51 \pm 2.7$ & $8.9 \pm 0.06$ \\
\hline La France & 4.84 & $77 \pm 2.0$ & $8.2 \pm 0.05$ \\
\hline La Marne & 4.84 & $89 \pm 0.3$ & $9.2 \pm 0.06$ \\
\hline Lemon Zest & 4.79 & $83 \pm 1.6$ & $8.6 \pm 0.06$ \\
\hline Libelle & 4.83 & $40 \pm 2.2$ & $9.1 \pm 0.07$ \\
\hline Lilacina & 4.46 & $71 \pm 0.6$ & $8.8 \pm 0.06$ \\
\hline Madame Emile Mouillère & 4.75 & $54 \pm 2.8$ & $8.3 \pm 0.06$ \\
\hline Mariesii & 4.73 & $7 \pm 3.6$ & $9.5 \pm 0.10$ \\
\hline Mariesii Variegata & 4.77 & $75 \pm 1.5$ & $9.7 \pm 0.07$ \\
\hline Mathilda Gütges & 4.79 & $41 \pm 3.8$ & $9.6 \pm 0.06$ \\
\hline Mousseline & 4.78 & $98 \pm 0.8$ & $8.0 \pm 0.05$ \\
\hline Niedersachen & 4.77 & $71 \pm 1.5$ & $8.4 \pm 0.06$ \\
\hline Nigra* & 4.83 & $74 \pm 2.1$ & $8.2 \pm 0.07$ \\
\hline Nikko Blue & 4.90 & $52 \pm 2.6$ & $8.3 \pm 0.06$ \\
\hline Oak Hill & 4.83 & $86 \pm 2.3$ & $8.4 \pm 0.05$ \\
\hline Otaska* & 4.78 & $84 \pm 2.2$ & $8.2 \pm 0.06$ \\
\hline Penny Mac & 4.79 & $62 \pm 4.8$ & $8.4 \pm 0.07$ \\
\hline Pia & 4.73 & - & - \\
\hline Pink Lacecap & 4.77 & $44 \pm 11.1$ & $8.7 \pm 0.07$ \\
\hline Princess Juliana & 4.78 & $95 \pm 0.6$ & $8.4 \pm 0.05$ \\
\hline Souvenir du Président Doumer & 4.84 & - & - \\
\hline Trophée & 4.64 & $55 \pm 8.3$ & $10.9 \pm 0.14$ \\
\hline Veitchii* & 4.64 & $56 \pm 1.8$ & $8.8 \pm 0.07$ \\
\hline White Wave (Mariesii Grandiflora) & 4.46 & $64 \pm 1.5$ & $9.0 \pm 0.06$ \\
\hline Zaunköenig & 4.77 & $83 \pm 1.6$ & $8.7 \pm 0.05$ \\
\hline \multicolumn{4}{|c|}{ Triploid H. macrophylla ssp. macrophylla cultivars } \\
\hline Altona & 7.10 & $67 \pm 1.8$ & $10.0 \pm 0.07$ \\
\hline Blaumeise* & 6.91 & $61 \pm 3.4$ & $9.3 \pm 0.06$ \\
\hline Domotoi & 7.16 & $74 \pm 1.9$ & $9.4 \pm 0.07$ \\
\hline Eisvogel* & 7.14 & - & - \\
\hline Enziandom & 7.27 & $70 \pm 1.1$ & $9.4 \pm 0.06$ \\
\hline Europa* & 7.20 & $63 \pm 0.9$ & $9.4 \pm 0.06$ \\
\hline Gertrude Glahn & 7.13 & $79 \pm 2.4$ & $9.3 \pm 0.09$ \\
\hline Hamburg & 7.23 & - & - \\
\hline Heinrich Seidel & 7.05 & $64 \pm 3.8$ & $10.2 \pm 0.09$ \\
\hline Holstein* & 7.18 & $67 \pm 1.8$ & $11.9 \pm 0.08$ \\
\hline Kardinal & 6.89 & $84 \pm 1.3$ & $9.1 \pm 0.06$ \\
\hline Maréchal Foch & 7.02 & $85 \pm 0.5$ & $9.4 \pm 0.06$ \\
\hline Masja & 7.22 & $25 \pm 12.2$ & $11.2 \pm 0.18$ \\
\hline Merritts Supreme & 7.04 & $49 \pm 1.7$ & $10.4 \pm 0.14$ \\
\hline Miss Hepburn & 7.12 & $66 \pm 1.2$ & $12.7 \pm 0.11$ \\
\hline Nachtigall* & 6.99 & $64 \pm 3.5$ & $10.2 \pm 0.08$ \\
\hline Oregon Pride & 7.08 & $57 \pm 5.7$ & $10.1 \pm 0.11$ \\
\hline Taube & 7.02 & $55 \pm 7.2$ & $9.7 \pm 0.08$ \\
\hline Tödi & 7.06 & $42 \pm 2.0$ & $12.8 \pm 0.11$ \\
\hline \multicolumn{4}{|c|}{ Diploid H. macrophylla ssp. serrata cultivars } \\
\hline Benigaku* & 4.36 & $88 \pm 1.9$ & $7.6 \pm 0.05$ \\
\hline Blue Billow & 4.39 & $95 \pm 0.8$ & $8.2 \pm 0.06$ \\
\hline Blue Bird* & 4.56 & $90 \pm 2.0$ & $8.4 \pm 0.06$ \\
\hline Coerulea & 4.58 & - & - \\
\hline Grayswood* & 4.44 & $44 \pm 3.0$ & $8.5 \pm 0.06$ \\
\hline Kiyosumi & 4.22 & $90 \pm 2.2$ & $7.6 \pm 0.06$ \\
\hline Komachi & 4.24 & - & - \\
\hline
\end{tabular}

continued 
Table 1. Ploidy, total nuclear DNA, percent stainable pollen, and pollen size of cultivars of two subspecies of Hydrangea macrophylla.

\begin{tabular}{lccc}
\hline & $\begin{array}{c}\text { Total nuclear } \\
\text { DNA, } \mathrm{pg}^{\mathrm{y}}\end{array}$ & $\begin{array}{c}\text { Stainable pollen, } \\
\%(\mathrm{mean} \pm \mathrm{SE})\end{array}$ & $\begin{array}{c}\text { Pollen grain } \\
\text { diam., } \mu \mathrm{m} \\
(\mathrm{mean} \pm \mathrm{sE})\end{array}$ \\
\hline Taxa $^{\mathrm{z}}$ & 4.13 & $94 \pm 2.0$ & $8.2 \pm 0.05$ \\
Little Geisha & 4.29 & - & - \\
Miyama-yae-Murasaki & 4.52 & $86 \pm 1.6$ & $8.8 \pm 0.06$ \\
Pri & 4.21 & $94 \pm 1.2$ & $7.9 \pm 0.05$ \\
Shichiosa* & 4.10 & - & - \\
Tokyo Delight & 4.60 & $94 \pm 0.8$ & $7.7 \pm 0.05$ \\
Woodlander & 4.56 & $90 \pm 0.1$ & $8.6 \pm 0.07$ \\
\hline
\end{tabular}

${ }^{2}$ Foreign letters in cultivar names are included in this table, but have been eliminated in text, other tables and figures. Valid synonyms and trademark names are listed in parentheses. Cultivars previously examined by Zonneveld (2004) indicated by asterisks (*).

yPloidy level and total nuclear DNA content as determined by flow cytometric measurements of DAPIstained nuclei.

cultivars were selected for stomatal measurements. The first pair of fully expanded leaves from mature plants growing under 63\% shadecloth was collected in Oct. 2005. Epidermal peels from the abaxial surface of the leaves were placed on microscope slides along with a drop of distilled water. Stomata were observed at $200 \times$ magnification and stomatal guard cell length measured using an ocular micrometer. Twenty stomata were measured on each of two leaves per cultivar. Statistical comparisons of stomatal guard cell length between diploid and triploid cultivars were made using a $t$ test.

Pollen measurements. Pollen was collected from greenhouse-grown plants between 19 May and 7 June 2006. With the exception of nine cultivars that did not flower in Spring 2006, pollen measurements were made on all cultivars for which ploidy had been determined through flow cytometry the previous year. On the day of anthesis, three anthers from a single flower were placed on a glass slide and squashed in a drop of $1 \%$ aceto-carmine. Digital images of three fields of view, each having $\approx 100$ to 200 pollen grains, were made from each slide using an Olympus BX-60 microscope equipped with an Olympus DP-70 digital camera (Olympus America, Melville, N.Y.). For each cultivar tested, three flowers were examined. Using the digital images, the diameter of 50 pollen grains from each flower was measured using MicroMeasure software, ver. 3.3 (Reeves and Tear, 2000). The frequency distribution of pollen grain size, in $0.3-\mu \mathrm{m}$ increments, was plotted for all diploid cultivars.

Number of stained and unstained pollen grains in each digital image was also determined. Lightly stained grains were scored as unstained. The percent stainable pollen in the three digital images of each flower was averaged to produce a mean percent stainable pollen for each of the three flowers examined.

Controlled pollinations. As part of an ongoing H. macrophylla breeding program, controlled pollinations were made during Summer 2004 and 2005. Although triploid cultivars were used in some of these pollinations, they were chosen as parents without knowledge of their ploidy level. Data from pollinations involving cultivars later found to be triploids were analyzed for the following: percent polli- nations producing seed, mean number of seed per successful pollination, and percent seed germination. Previously published pollination and seed germination procedures were used (Jones and Reed, 2006; Reed, 2005).

\section{Results and Discussion}

Flow cytometric measurements of total nuclear DNA identified both diploids and triploids among the 75 cultivars tested in this study (Table 1). Of the $61 \mathrm{H}$. macrophylla ssp. macrophylla cultivars examined, 42 were diploids and 19 were triploids. All 14 H. macrophylla ssp. serrata cultivars were diploid. Eleven of the H. macrophylla ssp. macrophylla and four of the H. macrophylla ssp. serrata cultivars that we tested were previously examined by Zonneveld (2004). Results of the two studies were in agreement for all but one cultivar, 'Holstein', which we found to be a triploid. 'Holstein' was developed by the same breeder who introduced three other triploids, 'Altona', 'Europa', and 'Hamburg' (van Gelderen and van Gelderen, 2004). However, because our 'Holstein' plant was acquired several years ago from another researcher, rather than directly from a nursery, it could have been mislabeled. Examination of additional specimens of this cultivar is needed to confirm its ploidy level.

DNA content ranged from 4.5 to $5.0 \mathrm{pg}$ in diploid $H$. macrophylla ssp. macrophylla, 6.9 to $7.3 \mathrm{pg}$ in triploid $H$. macrophylla ssp. macrophylla, and 4.1 to $4.6 \mathrm{pg}$ in H. macrophylla ssp. serrata cultivars (Table 1). For the 14 cultivars examined both in this study and by Zonneveld (2004) and for which there was agreement on ploidy, our DNA estimates were $2 \%$ to $10 \%$ higher than previously reported. However, DNA estimates have been shown to vary depending on the fluorochrome used (Doležel and Bartoš, 2005). DAPI, which we used, has a higher affinity for AT bases. DNA-intercalating fluorochromomes such as the propidium iodide used by Zonneveld (2004) show no base preference. The values presented in Table 1 likely slightly overestimate the total nuclear DNA content of the H. macrophylla cultivars.

The mean DNA content of all H. macrophylla ssp. serrata cultivars we studied was $4.36 \mathrm{pg}$, which was $9 \%$ less than the mean of
$4.77 \mathrm{pg}$ for the diploid H. macrophylla ssp. macrophylla cultivars in our study. These results are in general agreement with those of previous researchers who found $6 \%$ to $12 \%$ less DNA in H. macrophylla ssp. serrata than in H. macrophylla ssp. macrophylla (Cerbah et al., 2001; Zonneveld, 2004). Zonneveld (2004) used the differences in nuclear DNA between the two subspecies as justification for splitting them into separate species. However, as reviewed by Levin (2002), intraspecific differences in nuclear DNA content between populations from different geographic areas are not uncommon. Therefore, we do not believe that the difference in nuclear DNA content between the two subspecies is justification for elevating $H$. macrophylla ssp. serrata to the species rank.

Root tip cells of 'Dooley', 'Bailmer', and 'Veitchii' contained 36 chromosomes, whereas 'Domotoi', 'Nachtigall', and 'Taube' had 54 chromosomes. Like in previous studies with H. macrophylla (Cerbah et al., 2001; Demilly et al., 2000; Zonneveld, 2004), flow cytometric determinations of ploidy level corresponded to chromosome counts (Table 1; Fig. 1).

A consequence of genome doubling is larger cell size in polyploids relative to their diploid progenitors (Stebbins, 1950). Increases in stomatal guard cell and pollen grain sizes have been observed in polyploids of several plant species (Nagl, 1978). For the $10 \mathrm{H}$. macrophylla ssp. macrophylla cultivars examined, the mean stomatal length of the diploids $(30.6 \mu \mathrm{m})$ was significantly less than that of the triploids $(36.7 \mu \mathrm{m})$; however, there was overlap in measurements of individual diploid and triploid cultivars (Table 2). For example, the mean stomatal length of triploid 'Nachtigall' was the same as that of four of the five diploid cultivars. Differences in pollen grain size were observed among diploid H. macrophylla ssp. macrophylla $(8.7 \mu \mathrm{m})$, triploid H. macrophylla ssp. macrophylla $(10.3 \mu \mathrm{m})$, and $H$. macrophylla ssp. serrata $(8.2 \mu \mathrm{m})$ cultivars (Table 1). Like with stomatal guard size length, the range of values for the diploid $H$. macrophylla ssp. macrophylla cultivars (8.0 to $10.9 \mu \mathrm{m}$ ) overlapped that of the triploid $H$. macrophylla ssp. macrophylla cultivars (9.1 to $12.8 \mu \mathrm{m})$. Although guard cell and pollen grain measurements do not appear to be useful for determining ploidy of $H$. macrophylla cultivars, they may have value in other applications such as identifying polyploid plants created through chromosome doubling of a cultivar of known ploidy level.

Fertility of triploids varies widely among plant species and is dependent on frequency and type of trivalents formed at metaphase I and the tolerance of gametes to aneuploidy (Singh, 1993). Differences in percent stainable pollen were observed among and within diploid H. macrophylla ssp. macrophylla, triploid $H$. macrophylla ssp. macrophylla, and $H$. macrophylla ssp. serrata groups of cultivars. Stainable pollen for the diploid $H$. macrophylla ssp. macrophylla cultivars averaged $70 \%$ and ranged from $7 \%$ in 'Mariesii' 

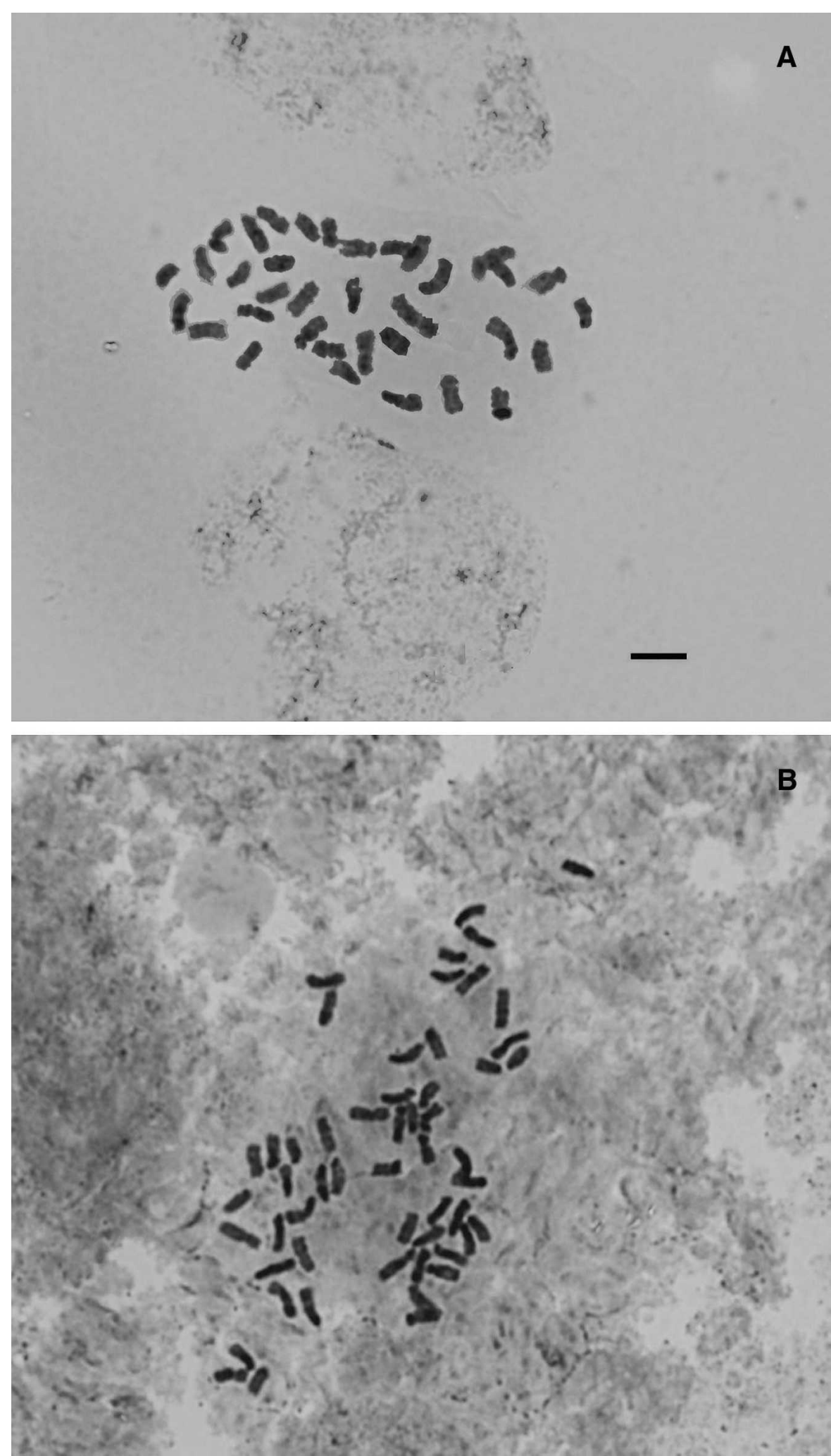

Fig. 1. Root tip chromosomes of Hydrangea macrophylla ssp. macrophylla. (A) 'Veitchii' $(2 n=2 x=36)$ and (B) 'Taube' $(2 n=3 x=54)$. Images at same magnification; bar $=2.5 \mu \mathrm{m}$.

to $98 \%$ in 'Ayesha' and 'Mousseline' (Table 1). Other diploid H. macrophylla ssp. macrophylla cultivars that produced less than $50 \%$ stainable pollen were 'Elster', 'Mathilda Gutges', 'Libelle' and 'Pink Lacecap'. Stainable pollen for the triploid $H$. macrophylla ssp. macrophylla cultivars averaged 63\%
Table 2. Stomatal guard cell length in diploid and triploid cultivars of Hydrangea macrophylla ssp. macrophylla.

\begin{tabular}{lc}
\hline Cultivar & $\begin{array}{c}\text { Stomatal guard } \\
\text { cell length, } \\
(\mu \mathrm{m}), \text { mean } \pm \mathrm{SE}\end{array}$ \\
\hline $\begin{array}{l}\text { Diploid cultivars } \\
\text { Bailmer } \\
\text { General Vicomtesse }\end{array}$ & $29.5 \pm 0.3$ \\
$\quad$ de Vibraye & $30.8 \pm 0.5$ \\
Nikko Blue & $30.8 \pm 0.4$ \\
Princess Juliana & $30.8 \pm 0.4$ \\
$\quad$ Zaunkoening & $31.1 \pm 0.4$ \\
Triploid cultivars & \\
Domotoi & $40.1 \pm 0.7$ \\
Merritts Supreme & $36.4 \pm 0.6$ \\
Miss Hepburn & $33.6 \pm 0.6$ \\
Nachtigall & $30.9 \pm 0.4$ \\
Oregon Pride & $35.2 \pm 0.5$ \\
\hline
\end{tabular}

'Grayswood' was the only H. macrophylla ssp. serrata cultivar to have less than $50 \%$ stainable pollen.

Pollen staining estimates of fertility may not be accurate because not all stainable grains may actually be viable. However, results of controlled pollinations confirmed partial fertility in five of six H. macrophylla ssp. macrophylla triploid cultivars. Only 'Merritt's Supreme' failed to produce viable seed when crossed to a diploid H. macrophylla ssp. macrophylla cultivar (Table 3). Viable seed were obtained when 'Blaumeise', 'Kardinal', 'Marechal Foch', and 'Nachtigall' were used as pistillate or staminate parents, whereas 'Taube' produced seed only when it was used a pistillate parent. Comparisons between cultivars and negative results presented in Table 3 should be viewed with caution because, with the exception of 'Kardinal', none of the triploids were crossed to more than two diploid cultivars.

Several of the diploid H. macrophylla ssp. macrophylla cultivars exhibited low percentages of stainable pollen with two diploids, 'Elster' and 'Mariesii', having less stainable pollen than any triploid cultivar. Because no diploid cultivar with less than $50 \%$ stainable pollen were included in the cytological study, the possibility that this low fertility is a result of aneuploidy cannot be ruled out. Somatic chromosome counts and meiotic analysis may help in determining the cause of low fertility among $H$. macrophylla diploid cultivars.

Autotriploids are produced experimentally from hybridization of tetraploid and diploid individuals, but in nature, they usually arise from the union of unreduced $(2 n)$ and haploid (n) gametes. Unreduced gametes have been documented in many plant species (Harlan and De Wet, 1975). As reviewed by Bretagnolle and Thompson (1995), frequency of unreduced gametes varies both among and within species. In addition to a genetic component, environment may affect the frequency of unreduced gamete production.

With the exception of 'Domotoi', an old Japanese cultivar that may have been selected from the wild, the other triploids identified in this study were the result of breeding efforts 


\begin{tabular}{|c|c|c|c|c|c|c|}
\hline Cultivar & Parental type & $\begin{array}{c}\text { No. of parental } \\
\text { combinations tested }\end{array}$ & $\begin{array}{c}\text { No. of pollinations } \\
\text { attempted }\end{array}$ & $\begin{array}{l}\text { Percent pollinations } \\
\text { producing seed }\end{array}$ & $\begin{array}{c}\text { Mean no. of seed/ } \\
\text { successful } \\
\text { pollination }\end{array}$ & $\begin{array}{l}\text { Percent seed } \\
\text { germination }\end{array}$ \\
\hline \multirow[t]{2}{*}{ Blaumeise } & Pistillate & 2 & 139 & 89.9 & 20.1 & 27.9 \\
\hline & Staminate & 2 & 135 & 18.5 & 8.9 & 15.8 \\
\hline \multirow[t]{2}{*}{ Kardinal } & Pistillate & 5 & 453 & 21.4 & 4.5 & 0.2 \\
\hline & Staminate & 5 & 312 & 13.5 & 12.1 & 27.2 \\
\hline \multirow[t]{2}{*}{ Marechal Foch } & Pistillate & 1 & 19 & 78.9 & 6.7 & 39.0 \\
\hline & Staminate & 1 & 93 & 4.3 & 9.8 & 5.3 \\
\hline \multirow[t]{2}{*}{ Merritts Supreme } & Pistillate & 1 & 61 & 0 & - & - \\
\hline & Staminate & 1 & 58 & 0 & - & - \\
\hline \multirow[t]{2}{*}{ Nachtigall } & Pistillate & 1 & 45 & 84.4 & 9.1 & 20.1 \\
\hline & Staminate & 1 & 57 & 10.5 & 10.3 & 12.9 \\
\hline \multirow[t]{2}{*}{ Taube } & Pistillate & 1 & 32 & 90.6 & 6.9 & 50.0 \\
\hline & Staminate & 1 & 20 & 0 & - & - \\
\hline
\end{tabular}

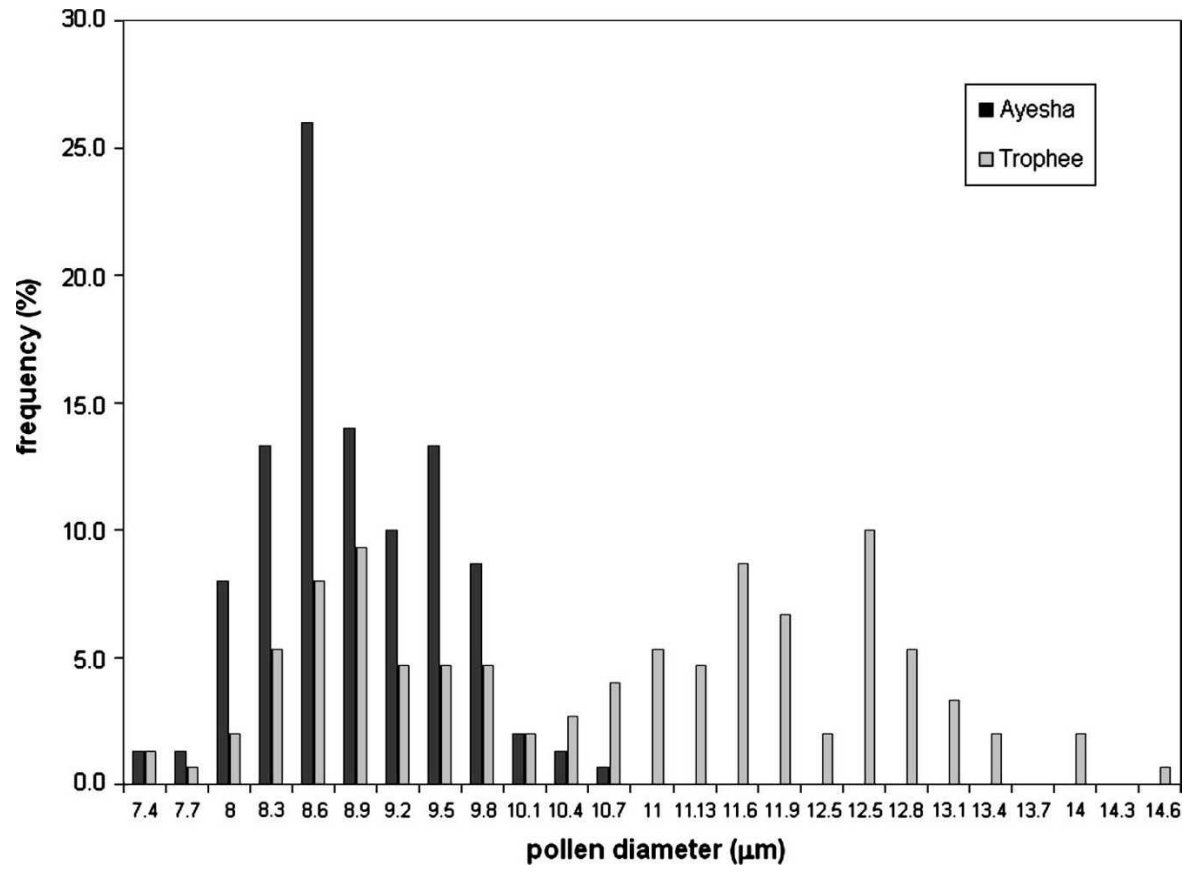

Fig. 2. Frequency distribution of pollen grain diameter in two diploid cultivars of Hydrangea macrophylla ssp. macrophylla. Values on x-axis represent $0.3 \mu \mathrm{m}$ range (e.g., 7.4 peak consists of pollen grains ranging from 7.40 to $7.69 \mu \mathrm{m}$ in diameter); $\mathrm{n}=150$.

(Haworth-Booth, 1984; Mallet, 1994; Mallet et al., 1992; van Gelderen and van Gelderen, 2004). Several triploids were produced by the same breeders. Two German breeders, $\mathrm{H}$. Schadendorff and F. Matthes, were responsible for six triploid cultivars, whereas another six were released by the Federal Research Institute for Horticulture in Switzerland (Mallet, 1994; van Gelderen and van Gelderen, 2004). It is not known whether these and other European breeders had access to tetraploid forms of $H$. macrophylla that were not included in previous ploidy analyses (Cerbah et al., 2001; Demilly et al., 2000; Zonneveld, 2004) or if they were using parental stocks that produced unreduced gametes. An additional possibility, considering the fertility of the triploids, is that a triploid parent may have been used in the breeding of additional triploids.

The most direct method of screening for unreduced pollen grains is the examination of the range of pollen sizes produced by an individual (Bretagnolle and Thompson, 1995). The presence of "giant" pollen has been associated with $2 \mathrm{n}$ status and has been used as an indicator of unreduced gamete formation. The frequency distribution of pollen grain size among diploid cultivars in this study was examined for evidence of unreduced gamete production. Pollen size distribution patterns were similar in all H. macrophylla spp. serrata and most diploid H. macrophylla ssp. macrophylla cultivars. These cultivars exhibited a range of pollen grain sizes that peaked at or near the mean value, but most produced a few grains considerably larger than the mean size (Fig. 2). The only cultivar that deviated substantially from this pattern was 'Trophee', which displayed a bimodal distribution. In Solanum L. and Dactylis L., a bimodal distribution of pollen size frequencies was associated with 2n pollen production (Quinn et al., 1974; van Santen, 1988). Analysis of microsporogenesis in 'Trophee' is needed to determine whether the large pollen grains observed in this cultivar represent unreduced gametes.

In summary, the ploidy level of a diverse group of $H$. macrophylla cultivars was identified using flow cytometry. Stomatal guard cell length and pollen diameter of H. macrophylla ssp. macrophylla diploid cultivars were substantially smaller than those of triploid cultivars. However, because the range of measurements for the diploids overlapped that of the triploids, neither guard cell nor pollen measurements are recommended for determining the ploidy of $H$. macrophylla cultivars. Both pollen staining and controlled pollinations indicated that some triploid cultivars had moderate to high fertility. A bimodal distribution of pollen sizes, which is suggestive of unreduced gamete production, was observed in one cultivar; however, more detailed genetic and cytological studies are needed to elucidate the mechanism behind triploid formation in H. macrophylla.

\section{Literature Cited}

Bailey, D.A. 1989. Hydrangea production. Timber Press, Portland, Ore.

Bertrand, H. 2001. Preliminary Hydrangea checklist. Institut National d'Horticulture, Angers, France.

Bretagnolle, F. and J.D. Thompson. 1995. Gametes with the somatic chromosome number: Mechanisms of their formation and role in the evolution of autopolyploid plants. New Phytol. 129:1-22.

Cerbah, M., E. Mortreau, S. Brown, S. SiljakYakovlev, H. Bertrand, and C. Lambert. 2001. Genome size variation and species relationships in the genus Hydrangea. Theor. Appl. Genet. 103:45-51.

Demilly, D., C. Lambert, and H. Bertrand. 2000. Diversity of nuclear DNA contents of Hydrangea. Acta Hort. 508:281-284.

Dirr, M.A. 2004. Hydrangeas for American gardens. Timber Press, Portland, Ore.

Doležel, J. and J. Bartoš. 2005. Plant DNA flow cytometry and estimation of nuclear genome size. Ann. Bot. (Lond.) 95:99-110.

Funamoto, T. and R. Tanaka. 1988. Karyomorphological studies in some taxa of Hydrangea from Japan. La Kromosomo 49:1583-1594.

Harlan, J.R. and J.M.J. De Wet. 1975. On Ö. Winge and a prayer: The origins of polyploidy. Bot. Rev. 41:361-390.

Haworth-Booth, M. 1984. The hydrangeas. 5th Ed. Constable and Company, London. 
Jones, K.D. and S.M. Reed. 2006. Production and verification of $H$. arborescens 'Dardom' $\times H$. involucrata hybrids. HortScience 41:564-566.

Kudo, N. and Y. Niimi. 1999. Production of interspecific hybrids between Hydrangea macrophylla f. hortensia (Lam.) Rehd. and $H$. arborescens L. Jpn. Soc. Hort. Sci. 68:428439.

Levin, D.A. 2002. The role of chromosomal change in plant evolution. Oxford University Press, N.Y.

Mallet, C. 1994. Hydrangeas: Species and cultivars, Vol. 2. Centre d'Art Floral, Varengeville, France.

Mallet, C., R. Mallet, and H. van Trier. 1992. Hydrangeas: Species and cultivars. Vol. 1. Centre d'Art Floral, Varengeville, France.
McClintock, E. 1957. A monograph of the genus Hydrangea. Proc. Calif. Acad. Sci. 29:147-256.

Nagl, W. 1978. Endopolyploidy and polyteny in differentiation and evolution: Towards an understanding of quantitative and qualitative variation of nuclear DNA in ontogeny and phylogeny. North-Holland Publishing, N.Y.

Quinn, A.A., D.W.S. Mok, and S.J. Peloquin. 1974. Distribution and significance of diplandroids among the diploid Solanums. Am. Potato J. 51:16-21.

Reed, S.M. 2005. Pollination biology of Hydrangea macrophylla. HortScience 40:335-338.

Reeves, A. and J. Tear. 2000. MicroMeasure for Windows, version 3.3. 22 Mar. 2007. Free program distributed by the authors over the Internet from http://www.colostate.edu/Depts/ Biology/MicroMeasure.

Singh, R.J. 1993. Plant cytogenetics. CRC Press, Boca Raton, Fla.

Stebbins, G.L. 1950. Variation and evolution in plants. Columbia University Press, N.Y.

van Gelderen, C.J. and D.M. van Gelderen. 2004. Encyclopedia of hydrangeas. Timber Press, Portland, Ore.

van Santen, E. 1988. Germplasm transfer in Dactylis L. Univ. of Wis., Madison, $\mathrm{PhD}$ Thesis.

Zonneveld, B.J.M. 2004. Genome size in Hydrangea, p. 245-251. In C.J. van Gelderen and D.M van Gelderen (eds.). Encyclopedia of hydrangeas. Timber Press, Portland, Ore. 